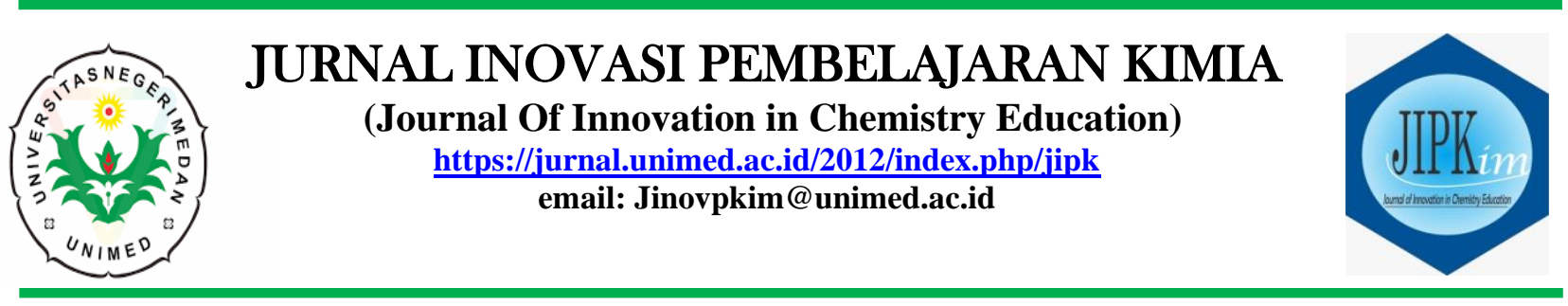

\title{
PEMBELAJARAN KIMIA MENGGUNAKAN REAL-LAB DAN VIRTUAL-LAB DITINJAU DARI KEMAMPUAN AWAL TERHADAP HASIL BELAJAR LAJU REAKSI
}

\author{
Anggita Efa Rizki ${ }^{\mathrm{a}, *}$, Feri Andi Syuhada ${ }^{\mathrm{a}}$ \\ ${ }^{a}$ Program Studi Pendidikan Kimia, Universitas Negeri Medan, Medan \\ *Alamat Korespondensi: anggitaefarizki@gmail.com
}

\begin{abstract}
:
The objective of this research is to determine the differences and interactions of student learning outcomes with real laboratories and virtual laboratories using the Guided Inquiry model. This research uses an experimental method with a $2 x 2$ factorial design. Samples were taken by purposive sampling. Data collection using test techniques for cognitive achievement. The data analysis technique uses two-way ANAVA technique. The research results by media factors (A) known $F_{\text {hit }}>F_{\text {table }}(48.37>4.08)$ then Ho is rejected means that there are differences in student learning outcomes with real laboratories and virtual laboratories using Guided Inquiry models. In the initial ability factor $(B)$ known $F_{\text {hit }}>F_{\text {table }}(14.61>4.08)$ then Ho is rejected means that there are differences in learning outcomes of students with high and low initial ability. In the interaction $(A x B)$ it is known that $F_{\text {hit }}>F_{\text {table }}(33.9>4.08)$ then Ho is rejected, meaning there is an interaction between students with real laboratories and virtual laboratory with different initial abilities towards learning outcomes.
\end{abstract}

Keywords:

Learning outcomes, Real laboratory, Virtual laboratory, Initial abilities, Guided Inquiry model

\section{PENDAHULUAN}

Seiring dengan perkembangan teknologi dan informasi yang cepat dalam berbagai aspek kehidupan pendidikan merupakan salah satu wadah untuk meningkatkan kualitas sumber daya manusia (Rismawati dkk., 2016). Pada abad ke-21, pemerintah telah menerapkan kurikulum 2013 sebagai salah satu cara untuk meningkatkan kualitas proses dan hasil belajar siswa (Hosnan, 2014).

Setiap proses pembelajaran diperlukan suatu strategi, metode, serta media pembelajaran yang dapat memberikan kesan positif kepada siswa terhadap kegiatan pembelajaran. Model inkuiri terbimbing dapat meningkatkan hasil belajar siswa, literasi sains, percaya diri siswa, kerja ilmiah siswa, penguasaan konsep, motivasi siswa dan konservasi karakter (Sundari dkk., 2017). Model pembelajaran inkuiri menerapkan langkah-langkah saintis dalam membangun pengetahuan melalui metode ilmiah sehingga penggunaan laboratorium dapat digunakan sebagai media pendukung (Rohmawati dkk., 2016). Pembelajaran inkuiri terbimbing yang dirangkaikan kegiatan praktikum di laboratorium pada materi laju reaksi menjadikan siswa lebih bersemangat dan termotivasi sehingga penguasaan konsep juga meningkat (Sundari dkk., 2017). 
Sutrisno (2011), laboratorium virtual merupakan situasi interaktif sains dengan bantuan aplikasi pada komputer berupa simulasi percobaan sains. Laboratorium virtual cukup digunakan untuk membantu proses pembelajaran dalam rangka meningkatkan pemahaman materi pada siswa dan juga baik digunakan untuk mengantisipasi terhadap ketidaksiapan praktikum di laboratorium.

\section{METODE}

Penelitian ini dilaksanakan di Kelas XI MIA semester ganjil 2019/2020 dengan menggunakan metode eksperimen. Desain penelitian yang digunakan adalah rancangan faktorial $2 \times 2$. Desain penelitian tercantum pada Tabel 1.

Tabel 1. Desain Penelitian

\begin{tabular}{cccc}
\hline \multirow{2}{*}{ Kelas } & $\begin{array}{c}\text { Media Pembe- } \\
\text { lajaran }(\mathrm{A})\end{array}$ & \multicolumn{2}{c}{ Kemampuan Awal $(\mathrm{B})$} \\
\cline { 3 - 4 } & $\mathrm{A}_{1}$ & Tinggi $\left(\mathrm{B}_{1}\right)$ & Rendah $\left(\mathrm{B}_{2}\right)$ \\
\hline Eksperimen I & $\mathrm{A}_{1} \mathrm{~B}_{1}$ & $\mathrm{~A}_{1} \mathrm{~B}_{2}$ \\
\hline Eksperimen II & $\mathrm{A}_{2}$ & $\mathrm{~A}_{2} \mathrm{~B}_{1}$ & $\mathrm{~A}_{2} \mathrm{~B}_{2}$ \\
\hline
\end{tabular}

Keterangan:

$\mathrm{A}_{1} \quad$ : Pembelajaran menggunakan

Real-Lab melalui guided inquiry

$\mathrm{A}_{2} \quad$ : Pembelajaran menggunakan

Virtual-Lab melalui guided inquiry

$\mathrm{B}_{1} \quad$ : Kemampuan awal tinggi

$\mathrm{B}_{2} \quad$ : Kemampuan awal rendah

$\mathrm{A}_{1} \mathrm{~B}_{1}$ : Pembelajaran menggunakan

Real-Lab pada siswa kemampuan awal tinggi

$\mathrm{A}_{2} \mathrm{~B}_{2}$ : Pembelajaran menggunakan

Virtual-Lab pada siswa kemampuan awal rendah

Populasi dalam penelitian ini adalah siswa kelas XI MIA yang terdiri dari 7 kelas. Pengambilan sampel dilakukan secara purposive sampling. Sampel penelitian yaitu kelas XI MIA 2 sebagai kelas eksperimen I (pembelajaran menggunakan Real-Lab) dan kelas XI MIA 4 sebagai kelas eksperimen II (pembelajaran menggunakan Virtual-Lab).

Variabel bebas dalam penelitian ini adalah pembelajaran menggunakan RealLab, Virtual-Lab dan kemampuan awal siswa, sedangkan variabel terikatnya adalah hasil belajar siswa.
Sumber data penelitian dalam penelitian ini berupa metode tes yaitu instrumen penilaian kognitif. Teknik analisis instrumen kognitif menggunakan: (1) Uji Validitas; (2) Uji Reliabilitas; (3) Tingkat Kesukaran; (4) Daya Pembeda; dan (5) Distruktor

Uji hipotesis menggunakan analisis dua jalan (anava dua jalan). Uji prasyarat meliputi normalitas dan uji homogenitas menggunakan uji Chi Kuadrat dan Uji F Hitung (Silitonga, 2014).

\section{HASIL DAN PEMBAHASAN}

Pada tahap awal dilakukan persyaratan analisis terhadap kondisi awal siswa kedua kelas eksperimen. Analisis diambil dari data perubahan hasil belajar siswa meliputi uji normalitas dan homogenitas.

Tabel 2. Rangkuman hasil uji normalitas

\begin{tabular}{cccc}
\hline \multirow{2}{*}{ Perlakuan } & \multicolumn{2}{c}{$\Delta \boldsymbol{x}$} & \\
\cline { 2 - 3 } & $\boldsymbol{X}^{\mathbf{2}}$ & $\boldsymbol{X}^{\mathbf{2}}$ tabel & Ket \\
& hit & & \\
\hline Real.Lab-Tinggi & 9,75 & 11,07 & Normal \\
\hline Real.Lab-Rendah & 10,59 & 11,07 & Normal \\
\hline Virtual- Tinggi & 6,23 & 11,07 & Normal \\
\hline Virtual-Rendah & 11,03 & 11,07 & Normal \\
\hline
\end{tabular}

Tabel 3. Rangkuman hasil uji homogenitas varians dua kelompok media pembelajaran

\begin{tabular}{|c|c|c|c|c|c|}
\hline \multicolumn{6}{|c|}{ Selisih nilai postest dengan pretest } \\
\hline \multicolumn{2}{|c|}{ Media Pembelajaran } & \multirow{2}{*}{$\mathbf{S}^{2}$} & \multirow{2}{*}{$\mathbf{F}_{\text {hit }}$} & \multirow{2}{*}{$\mathbf{F}_{\text {tabel }}$} & \multirow{2}{*}{ Ket } \\
\hline Lab Riil & Lab. Virt & & & & \\
\hline MIA 2 & & 0.39 & 2,52 & 2,97 & Homo-gen \\
\hline MIA 2 & & 0.15 & & & \\
\hline & MIA 4 & 0.19 & 2,05 & 2,97 & Homo-gen \\
\hline & MIA 4 & 0,39 & & & \\
\hline
\end{tabular}

Tabel 4. Rangkuman hasil uji homogenitas varians dua kelompok kemampuan awal siswa

\begin{tabular}{|c|c|c|c|c|c|}
\hline \multicolumn{6}{|c|}{ Selisih nilai postest dengan pretest } \\
\hline \multicolumn{2}{|c|}{$\begin{array}{c}\text { Kemampuan Awal } \\
\text { Siswa }\end{array}$} & \multirow[t]{2}{*}{$\mathbf{S}^{2}$} & \multirow[t]{2}{*}{$\mathbf{F}_{\text {hit }}$} & \multirow[t]{2}{*}{$\mathbf{F}_{\text {tabel }}$} & \multirow[t]{2}{*}{ Ket } \\
\hline Tinggi & Rendah & & & & \\
\hline MIA 2 & & 0.39 & 1,28 & 2,97 & Homo-gen \\
\hline MIA 4 & & 0,19 & & & \\
\hline & MIA 2 & 0.15 & 2,52 & 2,97 & Homo-gen \\
\hline & MIA 4 & 0,39 & & & \\
\hline
\end{tabular}

Berdasarkan hasil perhitungan dapat disimpulkan bahwa data hasil belajar siswa berdistribusi normal. Hasil analisis uji normalitas disajikan dalam Tabel 2 . Sedangkan uji homogenitas dimaksudkan 
untuk bahwa sampel adalah sampel yang homogen dengan taraf siginifikansi 0,05 yang dapat dilihat pada Tabel 3 dan Tabel 4 untuk setiap kombinasi perlakuan.

Setelah dilakukan persyaratan analisis, selanjutnya dilakukan analisis uji hipotesis terhadap hasil belajar ditinjau dari kemampuan awal dengan menggunakan uji statistik Anava dua jalur. Penelitian ini menunjukkan hasil analisis hipotesis sebagai berikut:

1. Berdasarkan hipotesis pertama dapat diketahui bahwa $F_{\text {hit }}(\mathrm{A})$ diperoleh 48,37 sedangkan $F_{\text {tabel }}(0,05)(1,40)=4,08$; karena $F_{\text {hit }}>F_{\text {tabel }}$ maka Ho ditolak berarti ada perbedaan hasil belajar siswa yang menggunakan Real-Lab dan Virtual-Lab menggunakan model pembelajaran Inkuiri Terbimbing.

2. Hipotesis kedua menunjukkan $F_{h i t}(B)$ diperoleh 14,61 sedangkan $F_{\text {tabel }}$ $(0,05)(1,40)=4,08$; karena $F_{\text {hit }}>F_{\text {tabel }}$ maka Ho ditolak berarti ada perbedaan hasil belajar siswa yang berkemampuan awal tinggi dan rendah.

3. Hipotesis ketiga menunjukkan bahwa $F_{\text {hit }}$ (AB) diperoleh 33,9 sedangkan $F_{\text {tabel }}$ $(0,05)=4,08$; karena $F_{\text {hit }}>F_{\text {tabel }}$ maka Ho ditolak berarti ada interaksi antara siswa yang menggunakan Real-Lab dan VirtualLab berkemampuan awal tinggi dan rendah terhadap hasil belajar menggunakan model pembelajaran inkuiri terbimbing.

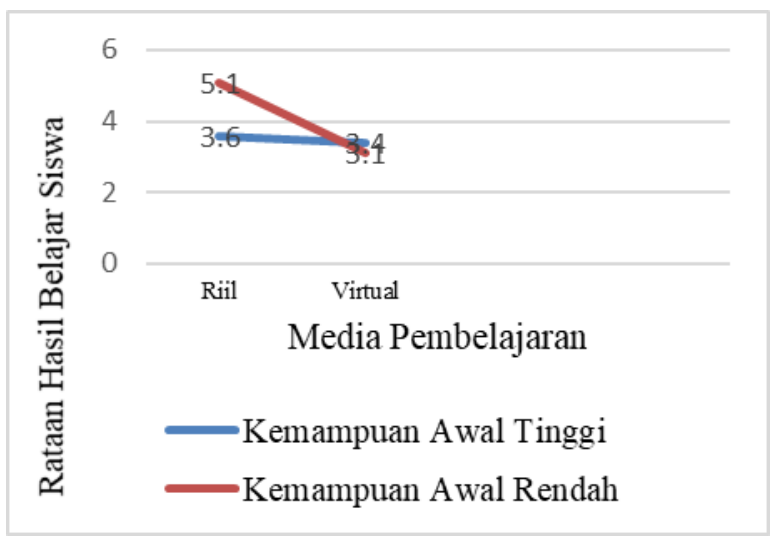

Gambar 1. Grafik Interaksi Faktor Media Pembelajaran dan Kemampuan Awal Siswa terhadap Hasil Belajar Siswa
Dari gambar grafik interaksi tersebut diketahui bahwa garis yang ada saling menyilang, sehingga dapat disimpulkan bahwa terdapat interaksi antara media pembelajaran yang digunakan dengan kemampuan awal siswa untuk hasil belajar siswa. Karena ada interaksi antar kedua faktor maka dilakukan uji lanjutan untuk mengetahui sejauh mana ketergantungan antara faktor media pembelajaran dengan kemampuan awal siswa yaitu dengan uji sederhana.

Pada pengujian sederhana faktor media pembelajaran untuk taraf B1 (kemampuan awal tinggi) didapatkan hasil bahwa $F_{\text {hit }}=0,7$ sedangkan $F_{\text {tabel }}(0,05)(1,20)$ $=4,35$; karena $F_{\text {hitung }}<\mathrm{F}_{\text {tabel }}$ maka Ho diterima berarti tidak ada perbedaan rataan nilai hasil belajar siswa yang memiliki kemampuan awal tinggi yang diajarkan dengan media pembelajaran yang berbeda. Hal ini disebabkan karena siswa yang memiliki kemampuan awal tinggi cenderung akan merasa tertantang menggunakan kemampuan berpikirnya untuk menemukan masalah dan penyelesaian masalah dengan cara penyelesaiannya sendiri sehingga dapat menemukan konsep yang diharapkan dengan caranya sendiri (Solihin, 2010). Dengan keinginan untuk selalu meningkatkan kemampuannya lalu belajar dengan menggunakan media pembelajaran yang kreatif dan inovatif maka semakin merangsang siswa untuk optimal dalam pembelajaran (Musakkir, 2015).

Pada pengujian sederhana faktor media untuk taraf B2 (kemampuan awal rendah) didapatkan hasil bahwa Fhit = 84,231 sedangkan Ftabel pada taraf 5\%= 4,35; karena Fhitung > Ftabel maka Ho ditolak berarti ada perbedaan yang siginifikan rataan hasil belajar siswa yang memiliki kemampuan awal rendah yang diajar dengan media pembelajaran yang berbeda. Selanjutnya dilakukan uji BNT, pada uji ini didapatkan bahwa BNT $(0,05)<$ $\left|\overline{Y_{1}}-\overline{Y_{2}}\right|$ atau $1,1<2,0454$. Oleh karena $\left|\overline{Y_{1}}-\overline{Y_{2}}\right|$ lebih besar dari BNT $(0,05)$ maka dapat disimpulkan bahwa rataan nilai hasil belajar siswa yang memiliki kemampuan 
awal rendah yang diberi pengajaran menggunakan Real-Lab berbeda nyata dengan nilai hasil belajar siswa yang diberi pengajaran dengan media Virtual-Lab. Diperoleh bahwa siswa yang memiliki kemampuan awal rendah cenderung lebih sesuai diberi perlakuan menggunakan Real$L a b$, terlihat dari rataan nilai yang lebih tinggi.

Tabel 5. Rataan hasil belajar siswa untuk setiap kombinasi perlakuan

\begin{tabular}{lcl}
\hline \multirow{2}{*}{$\begin{array}{c}\text { Faktor Kemampuan } \\
\text { Awal }(\mathrm{B})\end{array}$} & \multicolumn{2}{c}{ Faktor Media Pembelajaran $(\mathrm{A})$} \\
\cline { 2 - 3 } Tinggi $\left(\mathrm{B}_{1}\right)$ & Real-Lab $\left(\mathrm{A}_{1}\right)$ & Virtual-Lab $\left(\mathrm{A}_{2}\right)$ \\
\hline Rendah $\left(\mathrm{B}_{2}\right)$ & $3.591 \pm 0,6253$ & $3,409 \pm 0,437$ \\
\hline
\end{tabular}

Hal ini disebabkan karena siswa dengan kemampuan awal rendah akan lebih sulit untuk memahami konsep baru dibandingkan dengan siswa yang memiliki kemampuan awal tinggi jika dibelajarkan dengan bantuan media secara visual seperti gambar, grafik dan animasi dalam memahami suatu konsep (Setiawan, 2011). Selain itu, pembelajaran dengan menggunakan Real-Lab memberikan kesempatan kepada peserta didik untuk melakukan eksperimen dengan menggunakan alat dan bahan kimia secara konkret sehingga pembelajaran ini menyediakan pengalaman nyata yang menantang dan memenuhi keingintahuan siswa (Wahyuni, 2014) serta kegiatan praktikum di Real-Lab juga memiliki fungsi untuk mengembangkan proses berfikir peserta didik sehingga proses inkuiri dapat ikut berkembang. Dalam kegiatan praktikum melalui kerja laboratorium, peserta didik akan banyak menemukan gejala-gejala atau fenomena yang terjadi selama kegiatan eksperimen berlangsung (Hevriansyah, 2016). Sedangkan siswa yang memiliki kemampuan awal tinggi memiliki nilai rataan hasil belajar yang cenderung sama pada pemberian media pembelajaran yang berbeda namun rataan nilai hasil belajar siswa kemampuan awal tinggi dengan perlakuan kegiatan di laboratorium sedikit lebih tinggi dibandingkan dengan pemberian perlakuan Virtual-Lab.

\section{KESIMPULAN}

Berdasarkan hasil penelitian dapat disimpulkan bahwa ada perbedaan hasil belajar siswa yang menggunakan Real-Lab dan Virtual-Lab berkemampuan awal tinggi dan rendah pada materi laju reaksi menggunakan model pembelajaran inkuiri terbimbing. Hasil belajar siswa berkemampuan awal tinggi yang menggunakan Real-Lab dan Virtual-Lab tidak terdapat perbedaan yang signifikan, sedangkan hasil belajar siswa berkemampuan awal rendah lebih baik menggunakan Real-Lab dibandingkan dengan Virtual-Lab.

\section{DAFTAR PUSTAKA}

Hevriansyah, P., \& Megawanti, P., (2016). Pengaruh Kemampuan Awal terhadap Hasil Belajar Matematika, JKPM, 2(1):37-44.

Hosnan., (2014). Pendekatan Saintifik dan Kontekstual dalam Pembelajaran
Abad 21: Kunci Sukses Implementasi Kurikulum 2013, Ghalia Indonesia. Bogor.

Musakkir., (2015). Pengaruh Media Pembelajaran dan Motivasi Belajar terhadap Hasil Belajar Matematika Siswa Kelas IV Sekolah Dasar Kabupaten Tanah Tidung, Jurnal Pendidikan Dasar, 6(1):36-47.

Rismawati, K., Haryono., \& Mulyani, S., (2016). Studi Komparasi Penggunaan Media TTS dan Peta Konsep Melalui Model Pembelajaran Contextual Teaching and Learning (CTL) Ditinjau Dari Kemampuan Memori Terhadap Prestasi Belajar Siswa (Pokok Bahasan Koloid Kelas XI Semester Genap SMA Negeri 1 Karangmojo Tahun Pelajaran 2014/2015), Jurnal Pendidikan Kimia, 5(1):115-124.

Rohmawati, A., Masykuri, M., \& Utomo, S. B., (2016). Implementasi Pembelajaran Kimia dengan Inkuiri Bebas Termodifikasi Bermedia Laboratorium Riil dan Virtual Kelas XI Pokok Bahasan Sistem Koloid, 
Jurnal Pendidikan Kimia, 5(1):7177.

Setiawan, N. C., (2011). Pengaruh Model Pembelajaran dan Kemampuan Awal terhadap Hasil Belajar dan Kemampuan Berpikir Tingkat Tinggi Siswa Kelas XI IPA SMA Negeri 1 Turen pada Materi Kesetimbangan Kimia. Tesis, Universitas Negeri Malang.

Silitonga, P. M., (2014). Statistik : Teori dan Aplikasi dalam Penelitian, FMIPA UNIMED.

Solihin, I., (2010). Keefektifan Model Pembelajaran Inkuiri Terbuka dan Learning Cycle dalam Meningkatkan Kualitas Proses dan Hasil Belajar Kimia Siswa Kelas X SMA Negeri 3 Bontang, Tesis. Universitas Negeri Malang.

Sundari, T., Pursitasari, I. D., \& Heliawati, L., (2017). Pembelajaran Inkuiri Terbimbing Pada Topik Laju Reaksi, Jurnal Pendidikan Kimia, 6(2):1340-1347.

Sutrisno., (2011). Pengantar Pembelajaran Inovatif, Gaung Persada Press. Jakarta.

Wahyuni, T. S., (2014). Pengaruh Pembelajaran Inkuiri Terbimbing Menggunakan Real-Lab dan VirtualLab terhadap Pemahaman Representasi Kimia dan Motivasi Siswa pada Materi Kelarutan dan Hasil Kali Kelarutan. Tesis. Universitas Negeri Malang. 